\title{
The Use of Narrative Resources in a Career-counselling Course
}

\author{
Athanasios Verdis ${ }^{1}$, Spyros Kokkotas ${ }^{2} \&$ Lisa Dorli $^{3}$ \\ ${ }^{1}$ Assistant Professor in Educational Research and Evaluation, Pedagogical Department of Secondary Education, \\ School of Philosophy, National and Kapodistrian University of Athens, and Research Paths, Greece \\ ${ }^{2}$ Director, Research Paths, Greece \\ ${ }^{3}$ Pedagogical Department of Secondary Education, School of Philosophy, National and Kapodistrian University \\ of Athens, Greece
}

Correspondence: Athanasios Verdis, Assistant Professor in Educational Research and Evaluation, Pedagogical Department of Secondary Education, School of Philosophy, National and Kapodistrian University of Athens, Greece. Tel: 0030-210-727-7526. E-mail: oxoniana@gmail.com

Received: October 10, 2020

Accepted: January 10, $2021 \quad$ Online Published: February 20, 2021

doi:10.5539/hes.v11n1p183

URL: https://doi.org/10.5539/hes.v11n1p183

\begin{abstract}
In this paper, we analyse the communication codes in two consecutive meetings of a postgraduate class on career counselling held at the Department of Philosophy-Pedagogy-Psychology of the University of Athens in winter semester of 2017. The basic idea in these meetings was to discuss real-world situations with the help of a teaching framework and short films produced within the context of a European project, called 'Narrative Resources for Socio-Professional Inclusion' (NARSPI). The dialogs that followed the presentations were analysed with the help a sociolinguistic framework known as 'Legitimation Code Theory' (LCT). The analysis showed that the verbal communication moved from the particularities of the videotaped stories to discipline-specific vocabularies. According to LCT proponents, such moves in the use of language create wavelike forms of communication codes based on different levels of semantic gravity and semantic density. Such 'sematic waves' allow new ideas to be integrated into existing ideas and finally legitimise membership and scholarship in an academic field.
\end{abstract}

Keywords: social work education, career counselling, case stories, video

\section{Introduction}

The purpose of this paper is to analyse the communication codes in two consecutive meetings of a postgraduate class on career counselling and guidance held at the Department of Philosophy-Pedagogy-Psychology of the University of Athens during the winder semester of 2017. The basic idea in these meetings was that 'narrative resources' can be used as starting points for delving into specific theories in career counseling. The filming of the videos and the design of the lessons were products of a European project called 'Narrative Resources for Socio-Professional Inclusion' (NARSPI). The project comprised eight partners across different European countries. Two of the authors of the current paper are members of 'Research Paths', one of the partners of NARSPI. The resources are free to download from the project's webpage (NARSPI, 2017).

The dialogs that followed the presentation of the videos have been analysed with the help a sociolinguistic framework known as the Legitimation Code Theory (see Maton, 2000, 2007; Maton \& Moore, 2010). This framework is based on the sociolinguistic theory of Basil Bernstein (1999) on communication codes in education and also on the theory of Pierre Bourdieu on social field (Bourdieu \& Passeron, 1977). The Bernsteinian theory has been extended by the proponents of Legitimation Code Theory (LCT) so as to take account of different degrees of context-specificity and condensation of meaning in the micro level of the class. In addition, LCT theorists (Maton, 2014) introduce the 'epistemic-pedagogic device' in the social macro level for in order to describe knowledge practices across pedagogical fields. And this is where Bourdieu's field theory enters the picture. For LCT proponents, knowledge is crafted by members and scholars in academic disciplines (the 'knowers'), who engage themselves in strategic manoeuvres of power relations within Bourdieuian 'fields of struggles'.

In the above theoretical framework, our research questions concern the nature and the organising mechanisms of knowledge that has been crafted in these two meetings. The focus of our analysis shifts from micro processes of 
language to the legitimation of knowledge in the field of career counseling. Sources of data in our work are the dialogs between the postgraduate students and the first author of this paper, who happened to be their instructor. No recording of the verbal communications were made for this study. Instead, the researchers used their own notes after the lessons in a reflective form of qualitative inquiry (Elliot, 2005; Speedy, 2007). From an ethical point of view, participants' consent was asked in the beginning of each meeting. The use of narrative resources was integrated in the syllabus of the course and participation in the study was not based on the influence of the instructor.

\section{Literature Review}

\subsection{The Use of Filmed Case Stories in Teaching}

The use of narrative resources in higher education is a variation of the 'case method' (see Grandon, 2011). The 'cases' in this method are 'short, realistic, action-oriented stories, designed to raise issues' (Ruggiero, 2002, p. 115). The case method is being used nowadays as a teaching tool in a number of disciplines, such as pastoral and doctrinal care (Stivers, Gudorf, \& Martin-Schramm, 2012), management (Latusek, 2016), adult education (Clark \& Rossiter, 2008), and teacher education (Shulman, 1992; Gravett, de Beer, Odendaal-Kroon, \& Merseth, 2017). Byrne and Ragin (2009) discuss a number of practical and methodological issues in the use of the case method in higher education, while Grandon (2011) has given guidelines to faculty members interested in applying it.

With regards to filmed case stories, a number of studies have discussed the use of videos in higher education. Harper (2012), Papademas (2002), Russell and Kenna (2014), and Bach (2016) have discussed the use of films in teaching sociology. Similarly, Anderson (2017) has discussed the use of films in teaching social issues and has argued that digital storytelling can foster relationships and enable personal development. Ballantyne (2008) has examined the 'media versus method divide' and has presented the advantages and disadvantages of using new technologies versus the more traditional teaching methods in higher education.

Of special interest with regards the theme of our work is the book Social Work Live by Dorr (2014), in which the author discusses the use of filmed case stories in the identification of theories essential to clinical social work practice. In the first pages of her book, Dorr (2014) explains the basic pedagogical idea of her approach:

Attempting to find another method to help students make this important link between theory and practice, I tried incorporating video recorded interviews into class. By watching a video, students could begin to reflect on what theories were being used and articulate better how they figured this out (Dorr, 2014, p. xv).

The 'link between theory and practice' in the above extract, can be thought to delineate a special kind of knowledge. This knowledge is first of all a knowledge of the specific theories, like the 'ego' theory, the 'object relation theory', and a special 'system theory' used by the author in her book (Dorr, 2014). It is also a 'knower's' knowledge because it is based on the responses and the psychological standing of the individuals towards the specific cases and the specific people pictured in the films.

\subsection{Codes of Communication}

Codes are the organizing principles behind the language employed by members of a social group, according to Littlejohn (2002). The theoretical premise for communication codes in education has been postulated by the British sociologist Basil Bernstein, who has based his lifework on the study of the pedagogic practice as message system. With his notion of the 'pedagogic device' Bernstein theorised how educational codes in the fields of production, recontextualisation and dissemination of knowledge are linked to social class and power relations.

Maton (2014) has extended Bernstein's theory in the micro processes of the semantic so as to include the degree of context-specificity of codes ('semantic gravity') and the degree of condensation of codes ('semantic density'). According to Maton (2014), the stronger the semantic density (SD) in discourse, the more meaning is condensed within a sign or in a single notion or single practice. In our lessons, for example, we discussed the theory of Holland (1959) on personality types. We wrote the symbols of the personality types on the whiteboard. Each of these symbols signify a large number of meanings.

Semantic gravity (SG) on the other hand has to do with the degree to which a single symbol or a notion or a practice is connected to specific context. For example, if Holland's (1959) Artistic Personality is verbally unfurled within the context of a specific filmed case story or a specific clinical intervention, we say that its meaning is high on semantic gravity. In general, as notions get more and more depended on specific circumstances to make sense, their semantic gravity increases (van Krieken et al., 2014).

In the above theoretical framework Maton (2014, p. 16) has identified four possible communication codes in relation to their semantics (see Figure 1): (a) the rhizomatic code of low gravity and high density (SG-, SD+), 
where meanings are context-independent and highly complex (abstract concepts, specific brief terms of symbols), (b) the prosaic code of high gravity and low density (SG+, SD-), where meanings are simple and context-dependent (real world examples, with words used in their everyday meaning), (c) the rarefied code of low gravity and low density (SG-, SD-), where meanings are context-independent but also relatively simple (abstract concepts, common words used with their common meaning), and (d) the wordly code of high gravity and high density ( $\mathrm{SG}+, \mathrm{SD}+)$, where meanings refer to context-dependent practices and condense many other meanings. In the wordly code we have real word examples in condensed terms of symbols.

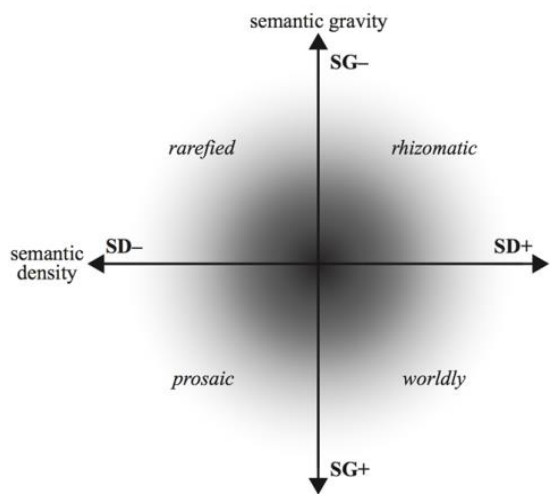

Figure 1. The semantic plane (from Maton, 2016, p. 16). Used with permission

Apart from focusing at the micro level of the semantics, Legitimation Code Theory has also focused on the macro level of the construction of knowledge. Maton (2010) has proposed a Cartesian frame, the vertical axis of which represents different degrees of epistemic relation between knowledge and its proclaimed object of study. The horizontal axis represents relations between knowledge and the 'knowers' who make claim to this knowledge. In this Cartesian system the communication codes of academic disciplines create strong $(+)$ and weak (-) 'epistemic relationships' (ER) among the scientific principles that inform the knowledge base of a discipline and also strong $(+)$ and weak $(-)$ 'social relationships' (SR) between practitioners and the authenticity of their practice. What legitimizes counselors in their field, therefore, is the possession of a special scientific knowledge and at the same time their social position as knowers in their field. A knowledge based legitimacy (ER+, SR-) is based on a strong knowledge base and on possessing theories relevant to the 'science' of that discipline. A knower based legitimacy (ER-, $\mathrm{SR}+$ ) is based on the dispositions or the 'gaze' of the practitioner, either because she or he is an insider to the community he or she is working with or due to his or her social position (e.g. being a woman, being an African-American etc.).

\section{The Films}

\subsection{First Film: 'Career Choices'}

The first film depicts a number of employees responding to questions asked by an unseen interviewer. The scenes have been shot at the houses of the interviewees but also at their workplaces. The participants are Elio, a retired worker, Jean-Michel, a firm director, Julien, an administrative coordinator, Martial, an accountant, Magali, a prison officer, and Maud, a psychologist. Different takes in this video portray utterances of the same or different interviewees. The scenes are separated by fade-ins and fade-outs. The actual questions are not heard but their content can be easily assumed. Cinematographically, the size of the shots is medium and there are close-ups to the faces of the respondents. Photographically the colors are warm, creating feelings of comfort and empathy. Most of the shots have been taken indoors and on low light. Some scenes are slightly underexposed, thus implying an evocative mood.

After the end of the film, the students commented on the strong and memorable impression of the participants, the stories of whom were said to be 'open' to many interpretations. Some students brought up issues related to social class and the 'Thatcherite policies' in Europe. They shared personal stories regarding their own job seeking at the so-called 'frontisteria', the evening learning centers (a form of shadow education in Greece), where many poorly paid students work. They mentioned the results of economic crisis in Greece by commending on the graffiti in the streets, the change in their family outings and eating habits, and a number of other issues related to their happiness and wellbeing. Many students expressed their personal fear of facing social exclusion in the near future. The purpose of our lesson, however, was far from being a starting point for discussing the 
politics and the social characteristics of the Greek economic crisis. Soon the discussion moved from the 'prosaic' language of everyday life to the discipline-specific theories that are used in career counseling and guidance.

The move from the language of the film to the language of clinical practice signaled for us a move from the prosaic code to the rarefied code, in the framework of LCT. Examples of a prosaic code were the phrases of Elio and Martial. The former, a retired worker, states that he wouldn't like to 'do the caravan every two years' (0 min, $16 \mathrm{sec}$ ) (See Figure 2). Martial, the accountant, states that he strives to 'avoid stress about tomorrow... and to maximize free time' ( $2 \mathrm{~min}, 55 \mathrm{sec} ; 3 \mathrm{~min} 10 \mathrm{sec}$ ). Similarly, Magali, the prison officer, describes how she chose to keep her job in the state sector instead of accepting a position related to her studies as a teacher ( $3 \mathrm{~min}, 40 \mathrm{sec})$ The prosaic code was also evident in the narration of Jean-Michel, the cinema director, who answered that he is not afraid of job insecurity 'because of [his] my history', $(1 \mathrm{~min}, 47 \mathrm{sec})$. Maud, the psychologist, says in the film that she is not afraid of job insecurity because 'security is not [her] my personal pursuit' $(4 \mathrm{~min}, 11 \mathrm{sec})$.

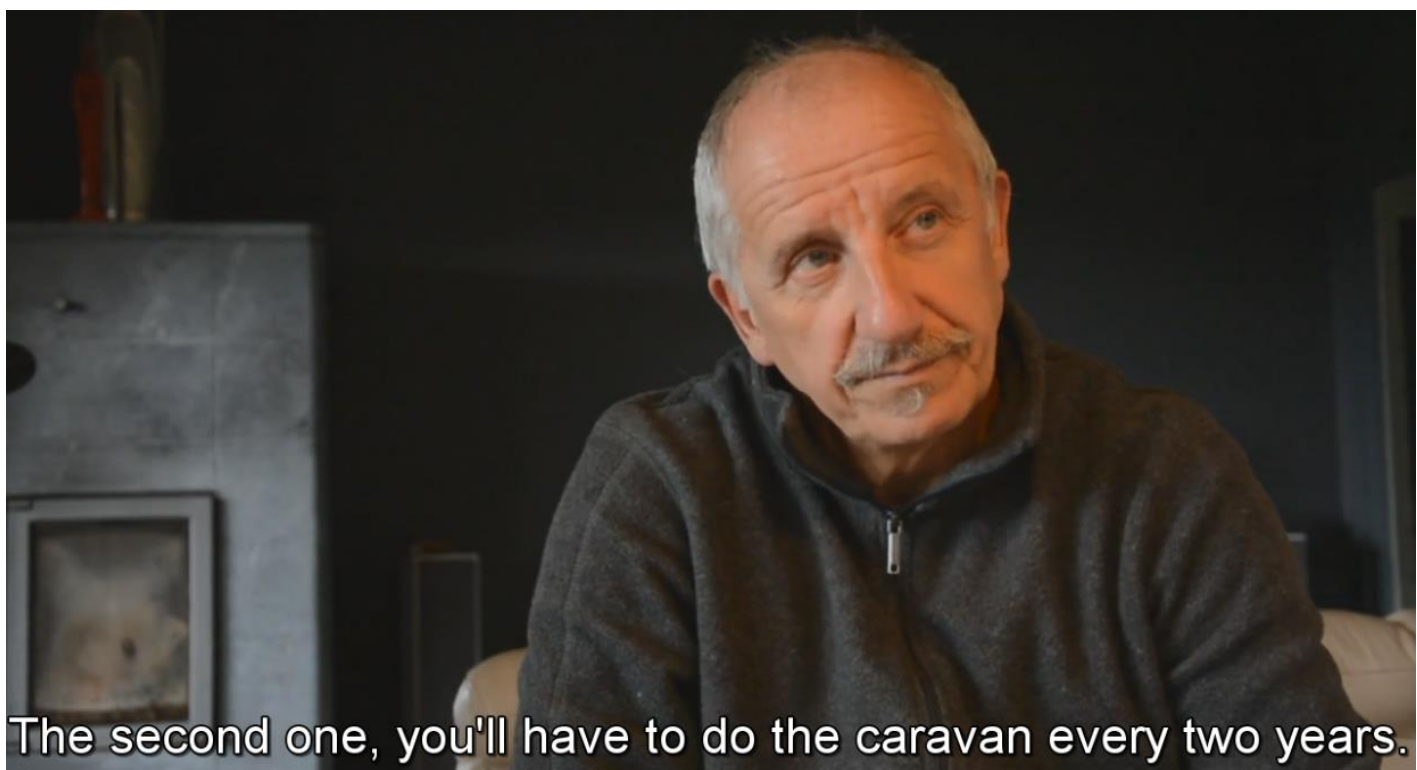

Figure 2. Elio, a retired worker, is being interviewed in a video created by the Belgian team 'Perspectives'

What interested students most about Maud was her explanations. Maud comes from a family of means where 'money [is] was not a problem' (4 min, $44 \mathrm{sec}$ ). She describes how she used to work during her studies. She says that her husband has had a job; that they have 'our [their] own house', and that 'the situation is ideal in order to have less stress' $(5 \mathrm{~min}, 10 \mathrm{sec}$ ). At that point, a student commented that Maud due to her social class origins lives in a safe environment and has never really faced the threat of social exclusion. Students also discussed Julien's story. Julien appears in the film to say that he likes to try different jobs, because 'society asks for more and more flexibility' ( $2 \mathrm{~min} 13 \mathrm{sec}$ ) and because 'security does not make any sense for me [him]' ( $2 \mathrm{~min}, 36 \mathrm{sec}$ ).

A student commented that Julien is essentially identifying parts of societal values as parts of himself. Julien's case was seen by the students as an example of 'social internalization'. Upon this, the instructor discussed a chapter from The Handbook of Socialization, by Grusec and Hastings (2015). The students were told that the stories in this video should be seen within the so-called 'dispositional approach', according to which job satisfaction is to some extent an individual trait (Jex \& Britt, 2015). Edwin Locke's 'affect theory' was also presented to the students as a basic background theory for understanding the stories in this video. According to this theory, job satisfaction is determined by a discrepancy between what one wants in a job and what one has in a job. It was explained that 'affect theory' claims that the value one ascribes to a given facet of work (e.g. the degree of autonomy) regulates the degree of his or her satisfaction. Finally, Holland's (1959) hexagon of occupational codes, which links job satisfaction to personality traits was drawn on the whiteboard. This was an example of the rhizomatic code.

\subsection{Second Film: 'Organisational Behaviour Ethics'}

In the title sequence of the second film, the viewers are informed that they are about to watch 'a story of fundamental attribution error ... a story of a new employee in a company, who faces a health problem'. In this 
film the camera is trained on the narrator, a social worker with French company Association Transfer. The narrator sits behind a table and is being filmed from his waist up. He wears a blue shirt. His eyes are soulful and the prosodic features of his speech manage to put the viewers directly into the story.

The narrator shares the story of a female employee in a French company (the names of which are not disclosed), who after an initial 'good start' appears as if she has faked sickness. Apparently, according to the narrator, the company makes an 'attribution error' (he uses this psychological term), by failing to recognize the employee's health condition. The narrator goes on to say that the reaction of the employer was to state that 'this person [the worker] doesn't work anymore' ( $2 \mathrm{~min} 20 \mathrm{sec})$, that 'she is not reliable' $(3 \mathrm{~min} 36 \mathrm{sec})$ and 'if it happens again she will lose her job' (3 $\mathrm{min} 42 \mathrm{sec}$ ). He describes his role in the situation as 'to demonstrate that we can't judge those situations at first sight' [ $\mathrm{sic}$ ( $3 \mathrm{~min} 25 \mathrm{sec}$ ). He explains the emotions of the employee, who probably faces 'a number of practical stressors', like 'caring for dependents, having her sense of self-reliance compromised, acquiring the identity of a sick person', and so on. According to the narrator, the employee 'felt carried' (4 min $25 \mathrm{sec}) \ldots$ in the procedure to materialize and prove the fact that she is in a situation that she cannot handle' (4 $\min 29 \mathrm{sec})$.

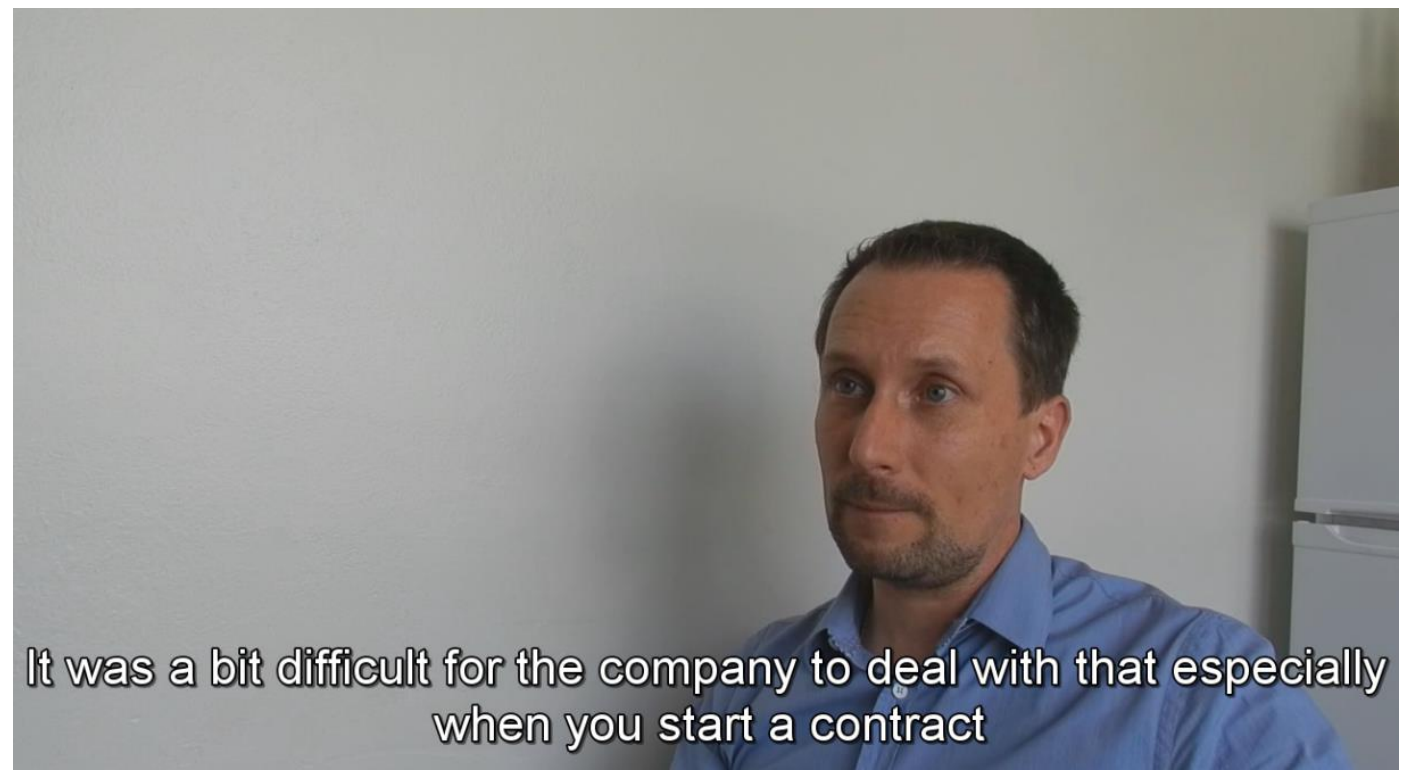

Figure 3. A social worker shares his experience from the field in a video created by the French team 'Association Transfer'

The narrator goes on to describe how he has helped the employee by not putting into question the truthfulness of her story $(4 \mathrm{~min} 40 \mathrm{sec})$. 'The situation' -he argues- 'should be settled on a meeting and in any case not from the telephone' (6 min $0 \mathrm{sec})$ in order to avoid 'bad understanding' [sic] (6 min $14 \mathrm{sec})$. 'A social worker's role' -he says- 'is to dissolve the errors-misconceptions by presenting the facts'. 'Look together the factual targets', he concludes $(6 \mathrm{~min} 44 \mathrm{sec})$. 'She [the employee] also suggested working overtime to facilitate the organization of the planning' $(7 \mathrm{~min} 5 \mathrm{sec})$. The narrator finishes his story by rhetorically asking at the camera: 'why negate the whole individual with just one element, the first element?' (7 min $40 \mathrm{sec}$ ). This last phrase points out not simply to the 'attribution error' but also to the issue of ethics in the workplace.

After watching the film, the students commended that they liked the idea of a trained counselor to be interviewed. They discussed the practical sides of organisational ethics with the help of the ideas found in the homonymous book of Johnson (2012). Two other textbooks were proposed to students: Workplace Morality, by Muel Kaptein (2013) and Organizational Behavior by Champoux (2011). A number of terms within the discipline of Organizational Psychology were discussed in relation to the film. These terms included the concept of a company's 'tunnel vision', i.e. the reluctance of employers to consider something different than their economic targets, the so-called 'halo effect', i.e. the situation in which an observer's overall impression of a person influences the observer's feelings, and the notion of 'organizational trust', i.e. employers' reliance on the actions of their employees. 


\section{Discussion}

In this paper, we have examined the use of narrative resources in a postgraduate course through the lenses of a theory in systemic functional linguistics that extents Basil Bernstein's theory of codes. The narrative recourses used in our classes and the design of the lessons have come from a European project called Narrative Resources of Socio-professional Inclusion (NARSPI). In our classes, the students watched two short films and made connections to their own experiences, dispositions and knowledge. The transition from prosaic code of the films to the rhizomatic code of academia created what Maton (2013, p. 18) has described as 'semantic waves'. In Figure 2 we demonstrate such a wave. Line (B) represents the prosaic code. Line (A) represents the discipline-specific codes of the theories. The distance between lines A and B represents the 'semantic range' between the two codes. The doted sigmoid lines (C) represent the 'semantic waves' that we have produced.

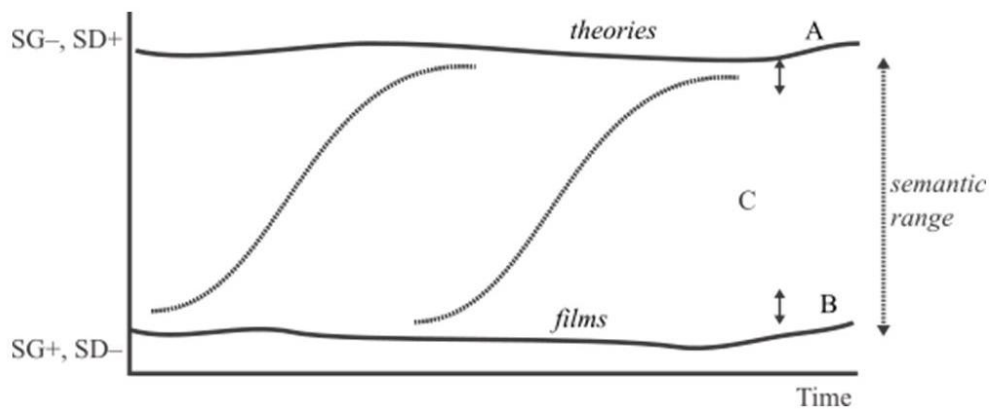

Figure 4. Upwards moving sigmoid lines of strengthening semantic density and weakening semantic gravity (adapted from Maton 2016, p. 17)

There are many different methods for the creation of semantic waves. The appearance of the narrator in the second film is a kind of cinematographic 'script', as Alexandra (2017) would argue. Not only does this narrator tell an interesting story but he also uses his silences and his facial expressions to create meaning, something that reminds us the importance of considering teaching as a multimodal event. According to Maton (2013), the upwards move of the semantic waves can help in the creation of 'cumulative' and thus 'powerful' codes of knowledge, thus allowing new ideas and skills to be extended and integrated into existing ideas or skills. Knowledge taken from narrative resources is thus transferred through semantic waves beyond the specific context of films and connects up with more discipline-specific meanings.

This is where Bourdieu's theory of field enters our discussion. Scholarship and membership in an academic field could be understood within what Bourdieu (1993) has called 'a field of struggles'. Bourdieuian fields are social settings in which the positions of the agents are results of their personal perceptions of the social world (habitus) and the forms of capital they can exchange (social, economic, cultural). The profession of career counselor is such a field because it is unregulated and its practitioners come from different academic backgrounds. According to van Esbroeck and Athanasiou (2008, p. 4), the diversity of the field of career counseling is 'not only related to cultural and linguistic differences but is also related to the many schisms and splits in the field of vocational psychology and guidance ... [that] started already in the 1930s'.

Career counseling is shaped by the contents, the methods and the communication codes of disciplines like Sociology, Economics, Education, and Psychology. In the framework that we use in our study, the Legitimation Code Theory, a strong knowledge base and the use of academic language can help in the creation of epistemic relationships within the career counseling profession. The films, with their evocative and cinematographic language, can help in the development future career counselors' 'cultivated gaze'. If legitimacy in a profession is based on possessing a specialist's type of knowledge but also on being the 'right kind of knower', the videos and the pedagogical ideas of the NARSPI (2017) have helped in that direction.

\section{References}

Alexandra, D. (2017). Implicating practice: engaged scholarship through storytelling. In G. Jamissen, P. Hardy, Y. Nordkvelle, \& H. Pleasants (Eds.), Digital storytelling in higher education: international perspectives (pp. 335-354). Cham, Switzerland: Palgrave Macmillan.

Anderson, K. (2017). Let's get personal: digital stories for transformational learning in social work students. In G. Jamissen, P. Hardy, Y. Nordkvelle, \& H. Pleasants (Eds.), Digital storytelling in higher education: international perspectives (pp. 73-90). Cham, Switzerland: Palgrave Macmillan. 
https://doi.org/10.1007/978-3-319-51058-3_6

Bach, J. (2016). Reel education: documentaries, biopics, and reality television. New York, NY: Peter Lang Publishing. https://doi.org/10.3726/978-1-4539-1880-7

Ballantyne, N. (2008). Multimedia learning and social work education. Social Work Education, 27(6), 613-622. https://doi.org/10.1080/02615470802201655

Bernstein, B. (1999). Vertical and horizontal discourse: An essay. British Journal of Sociology of Education, 20(2), 157-173. https://doi.org/10.1080/01425699995380

Bourdieu, P. (1993). The field of cultural production. Polity Press, Oxford

Bourdieu, P., \& Passeron, J. (1977). Reproduction in education, society and culture. London: Sage.

Brandell, J. (Ed.). (2011). Theory and practice in clinical social work. Thousand Oaks, CA: Sage.

Champoux, J. E. (2011). Organizational behaviour: integrating individuals, groups, and organizations. New York and London: Routledge. https://doi.org/10.4324/9780203872918

Dorr, C. (2014). Social work live. Oxford: Oxford University Press.

Edwards, R., \& Holland, J. (Eds.). (2013). What is qualitative interviewing? "What is?" Research Methods Series (Vol. 7). London \& New York: Bloomsbury Academic.

Elliot, J. (2005). Using narrative in social research: qualitative and quantitative approaches. Thousand Oaks CA: Sage. https://doi.org/10.4135/9780857020246

Grusec, J., \& Hastings, P. (Eds.). (2015). The handbook of socialization: theory and research. New York, NY: Guilford Press.

Harper, D. (2012). Visual sociology. London: Routledge. https://doi.org/10.4324/9780203872673

Holland, J. (1959). A theory of vocational choice. Journal of Counseling Psychology, 6(1), 35-45. https://doi.org/10.1037/h0040767

Johnson, G. (2012). Organizational ethics: practical approach. Thousand Oaks, CA: Sage.

Jones, K. (2005). Widening the lens: the efficacy of the case method in helping direct practice MSW students understand and apply mezzo and macro dimensions of practice. Social Work Education, 24(2), 197-211. https://doi.org/10.1080/0261547052000333135

Kaptein, M. (2013). Workplace morality: behavioral ethics in organizations. Bingley, UK: Emerald.

Littlejohn, S. (2002).Theories of human communication. Belmont, CA:Wadsworth-Thomson Learning

Maton, K. (2000). Languages of legitimation: the structuring significance for intellectual fields of strategic knowledge claims. British Journal of Sociology of Education, 21(2), 147-167. https://doi.org/10.1080/713655351

Maton, K. (2007). Knowledge-knower structures in intellectual and educational fields. In F. Christie \& J. Martin (Eds.), Language, knowledge and pedagogy (pp. 87-108). London: Continuum.

Maton, K. (2013). Making semantic waves: a key to cumulative knowledge-building. Linguistics and Education, 24(1), 8-22. https://doi.org/10.1016/j.linged.2012.11.005

Maton, K. (2014). Building powerful knowledge: the significance of semantic waves. In E. Rata \& B. Barrett (Eds.), The future of knowledge and the curriculum (pp. 181-197). London: Palgrave Macmillan. https://doi.org/10.1057/9781137429261_12

Maton, K. (2016). Legitimation Code Theory: building knowledge about knowledge-building. In K. Maton, S. Hood, \& S. Shay (Eds.), Knowledge-building: educational studies in Legitimation Code Theory (pp. 1-24). Abingdon, Oxon, UK: Routledge. https://doi.org/10.4324/9781315672342

Maton, K., \& Moore, R. (2010). Social Realism, knowledge and the sociology of education. London \& New York: Continuum.

Moreno, R. (2006). Learning in high-tech and multimedia learning environments. Current Directions in Psychological Science, 15(2), 63-67. https://doi.org/10.1111/j.0963-7214.2006.00408.x

NARSPI. (2017). Narrative recourses for socio-professional inclusion. Retrieved from http://narspi.org/

Papademas, D. (2002). Visual Sociology: teaching with film/video, photography, and visual media. Washington, DC: American Sociological Association. 
Russell, W., \& Kenna, J. (2014). Using films to address social issues in the classroom. In S. Totten \& J. Pedersen's (Eds.), Teaching about Social Issues in the 20th and 21th centuries (pp. 177-196). Charlotte, NC: Information Age Publishing.

Sharma, P. (2016). Theories of career development: educational and counseling implications. Journal of Indian Psychology, 3(4), 214-223.

Speedy, J. (2007). Narrative inquiry and psychotherapy. London: Palgrave Macmillan. https://doi.org/10.1007/978-1-137-02155-7

van Krieken, R., Habibis, D., Smith, P., Hutchins, B., Martin, G., \& Maton, K. (2014). Sociology. Pearson Higher Education Australia.

\section{Copyrights}

Copyright for this article is retained by the author(s), with first publication rights granted to the journal.

This is an open-access article distributed under the terms and conditions of the Creative Commons Attribution license (http://creativecommons.org/licenses/by/4.0/). 